\title{
Pretreatment of vinasse from the sugar refinery industry under non-sterile conditions by Trametes versicolor in a fluidized bed bioreactor and its effect when coupled to an UASB reactor
}

\author{
Elda España-Gamboa ${ }^{1}$, Teresa Vicent ${ }^{2}$, Xavier Font ${ }^{2}$, Jorge Dominguez-Maldonado ${ }^{1}$, Blondy Canto-Canché \\ and Liliana Alzate-Gaviria ${ }^{*}$
}

\begin{abstract}
Background: During hydrous ethanol production from the sugar refinery industry in Mexico, vinasse is generated. Phenolic compounds and melanoidins contribute to its color and make degradation of the vinasse a difficult task. Although anaerobic digestion (AD) is feasible for vinasse treatment, the presence of recalcitrant compounds can be toxic or inhibitory for anaerobic microorganism. Therefore, this study presents new data on the coupled of the FBR (Fluidized Bed Bioreactor) to the UASB (Upflow Anaerobic Sludge Blanket) reactor under non-sterile conditions by T. versicolor. Nevertheless, for an industrial application, it is necessary to evaluate the performance in this kind of proposal system.
\end{abstract}

Results: Therefore, this study used a FBR for the removal of phenolic compounds (67\%) and COD (38\%) at non-sterile conditions. Continuous operation of the FBR was successfully for 26 days according to the literature. When the FBR was coupled to the UASB reactor, we obtained a better quality of effluent, furthermore methane content and yield were $74 \%$ and $0.18 \mathrm{~m}^{3} \mathrm{CH}_{4} / \mathrm{kg} \mathrm{COD}_{\text {removal }}$ respectively.

Conclusions: This study demonstrated the possibility of using for an industrial application the coupled of the FBR to the UASB reactor under non-sterile conditions. Continuous operation of the FBR was carried out successfully for 26 days, which is the highest value found in the literature.

Keywords: Hydrous ethanol vinasse, Trametes versicolor, Non-sterile conditions, Fluidized bed bioreactor, UASB, Recalcitrant compounds

\section{Background}

The production of alcohol from sugarcane and its derivatives is a very important industry in Mexico. In 2013, 17 million liters of hydrous ethanol were produced and it will be increased in the next years. A traditional ethanol plant produces between 9 and $14 \mathrm{l}$ of wastewater known as vinasse by liter of ethanol [1]. In general, vinasse is a

\footnotetext{
* Correspondence: lag@cicy.mx

YYucatan center for scientific research (CICY), Renewable Energy Unit and Biotechnology Unit. Street 43 N.130 Col. Chuburná de Hidalgo 97200, Merida, Yucatan, Mexico

Full list of author information is available at the end of the article
}

low $\mathrm{pH}$ brown-colored residue that exhibits high concentrations of organic and inorganic compounds. The presence of phenolic compounds $(8,000-10,000 \mathrm{mg} / \mathrm{L})$, melanoidins (result from the reaction of sugars and proteins by the Maillard reaction), caramel and the furfural components contribute to its color and make vinasse a complex and difficult wastewater for degradation $[1,2]$.

Vinasse also takes a high value as fertilizer, due to its high organic matter and micronutrients content is often used in crops fertigation. However, when used in large quantities, vinasse can saturate the soil and contaminate nearby water bodies. In Mexico, the application of crude 
vinasse to sugarcane crops has been observed to affect crop growth without reducing the amount of fertilizer. Thus, it is necessary to dilute vinasse to $10 \% \mathrm{v} / \mathrm{v}$ with water in order to use it in fertigation. Recently, González and Mejía [3] determined the effect of fertigation with vinasse over 50 years on the groundwater quality of an aquifer in the east central region of Mexico. They found that the aquifer has the potential to be contaminated by deep percolation of irrigation water. Therefore, a conditioning treatment must be applied to this wastewater before it is disposed of in the environment.

An anaerobic treatment of vinasse has often been cited as an effective and economical treatment option because it eliminates the chemical oxygen demand (COD) and converts it to biogas, which is a readily usable fuel for the ethanol facility $[4,5]$. However, although anaerobic digestion of most types of vinasses is feasible and quite appealing from an energy point of view, the presence of recalcitrant compounds can be toxic or inhibitory for anaerobic microorganism, commonly phenols, melanoidins, and a variety of sugar decomposition products. This slows down the kinetics and reduces mean rates of methane production and yield coefficients $[4,6,7]$. Moreover, the presence of phenolic compounds in drinking and irrigation water represents a health and environmental hazard.

An option for the elimination of phenolic compounds and melanoidins is the use of white rot fungi, which, when cultured under appropriate conditions, produce extracellular enzymes include manganese peroxidase, lignin peroxidases, and laccases that are capable of breaking a lot of different chemical bonds [8]. Laccases catalyze the oxidation of various aromatic compounds, specifically phenolic compounds (ortho- and para-diphenols, aminophenols and polyphenols), anilines, polyamines and aryl diamines, as well as some inorganic ions while concomitantly reducing molecular oxygen to water [9]. Likewise, it is found in the literature that the laccases are characterized by the presence of copper centers inside their catalytic core. These enzymes contain at least one type-1 copper (T1), which gives the characteristic blue color, together with at least three additional copper ions: one type-2 (T2) and two type-3 (T3) copper ions, arranged in a trinuclear cluster. The oxidation of the substrate occurs at the T1 copper site, and the extracted electrons are transferred through a His-Cys-His tripeptide sequence to T2/T3 site where the reduction of molecular oxygen in water occurs [10-12]; thus has been reported that when small anions are bound in the T2 and T3 copper atoms the internal electron transfer is disturbed and the laccase is inhibited. Also the laccase inhibition may occur through amino acid residue modification, copper chelation or conformational change of the enzyme. Although some substances may inhibit laccase activity, the addition of certain compounds can enhance its efficiency. For example $\left(\mathrm{NH}_{4}\right)_{2} \mathrm{SO}_{4}, \mathrm{~K}_{2} \mathrm{SO}_{4}$ and
$\mathrm{Na}_{2} \mathrm{SO}_{4}$ have been shown to improve activities of laccase produced by Sinorhizobium meliloti CE52G [12].

T. versicolor is a white rot fungus which is able to degrade and/or mineralize a wide range of pollutants resistant to other microorganisms, such as dyes, polychlorobiphenyls (PCBs), polycyclic aromatic hydrocarbons (PAHs), pesticides, pentachlorophenols and endocrine disruptors [13, 14]. T. versicolor is a promising option on treating vinasse; nevertheless, for an industrial application, it is necessary to evaluate the performance of vinasse degradation in a bioreactor. Borras et al. [15] developed a continuous process to degrade Gris Lanaset G (real textile dye) and their research team has experience with degradation of other kinds of pollutants, such as endocrine disruptors, pharmaceuticals, urban wastewater [13] and hospital wastewater [16] using T. versicolor in pellet form in a fluidized bed bioreactor.

The aim of this study was to develop an integrated treatment involving the use of a fluidized bed bioreactor inoculated with pellets of $T$. versicolor to degrade recalcitrant compounds contained in hydrous ethanol vinasse and later apply an anaerobic treatment in an UASB for biogas production. The performance of this system was compared with anaerobic digestion of fungally-untreated hydrous ethanol vinasse to assess if a fungal pretreatment step was beneficial.

\section{Methods}

\section{Fungus}

T. versicolor (ATCC\#42530), provided by the Department of Chemical Engineering (Universidad Autónoma de Barcelona, Barcelona, Spain), was used in all experiments. Pellet production was done as previously described by Font et al. [17]. Pellets obtained by this process were washed with sterile distilled water.

\section{Hydrous ethanol vinasse}

The vinasse was collected from "La Gloria" sugar refinery, located in the municipality of Úrsulo de Galván, Veracruz, Mexico. Some average characteristics of this wastewater are shown in Table 1. All parameters were analyzed according to analytical procedures shown below.

\begin{tabular}{ll}
\multicolumn{2}{l}{ Table $\mathbf{1}$ Hydrous ethanol vinasse characterization } \\
\hline Parameter & Value $^{\mathrm{a}}$ \\
\hline $\mathrm{pH}$ & $4.39 \pm 0.006$ \\
Phenolic compounds & $10,834 \pm 1476$ \\
$\mathrm{COD}$ & $110,065 \pm 11486$ \\
$\mathrm{SO}_{4}^{2-}$ & $5,300 \pm 1416$ \\
$\mathrm{TN}$ & $1,720 \pm 217$ \\
$\mathrm{~N}^{\mathrm{D}} \mathrm{NH}_{3}$ & $68 \pm 9$ \\
$\mathrm{PO}_{4}^{3-}$ & $415 \pm 67$ \\
\hline
\end{tabular}

${ }^{\mathrm{a} A l l}$ values except $\mathrm{pH}$ are expressed in $\mathrm{mg} / \mathrm{L}$

${ }^{\mathrm{b}}$ Expressed in gallic acid 


\section{Results and discussion}

Sterile and non-sterile batch fluidized bed bioreactor treatment

\section{Phenolic compounds and COD}

The effect of sterile and non-sterile conditions on the performance of bioreactor is shown in Fig. 1. In both conditions it was observed that $T$. versicolor is able to remove phenolic compounds. The initial phenolic concentration on the fluidized bed bioreactor was $1,122 \pm 59 \mathrm{mg} / \mathrm{L}$ and on day 6 a removal value of $64 \pm 0.21 \%$ and $67 \pm 19 \%$ in sterile and non-sterile condition, respectively, was registered. These values remained almost constant until the last day of experimentation (day 15). Similar behavior was registered for COD removal. The initial COD concentration was $12,120 \pm 496 \mathrm{mg} / \mathrm{L}$ and on day 6 in sterile condition a removal value of $41 \pm 3 \%$ and in non-sterile condition $38 \pm 5 \%$ was observed. The removal values, both phenolic compounds and COD, did not show significant difference according to statistical analysis.

The results obtained in both conditions (sterile and non-sterile) are quite interesting since the original phenol content was reduced substantially with a decrease in COD around $40 \%$. A similar result was obtained by García-García et al. [18] during fermentation in batchwise in a thoroughly mixed reactor using sterilized vinasse using Aspergillus terreus and Geotrichum candidum. The extent of removal in the fermentation by $A$. terreus of total phenols and o-diphenols was 66 and 94\%, respectively; the overall decrease in COD was about $29 \%$. In the case of G. candidum, the results were 70 and $91 \%$. The overall decrease in COD, in this case, was about $28 \%$.

\section{Laccase activity}

Laccase activity presented a different behavior in both conditions: in sterile, laccase registered a value of $960 \pm$ $23 \mathrm{U} / \mathrm{L}$ on day 4 and continued to increase slightly until day 15 , while in non-sterile condition maximum value was observed on day $6(1485 \pm 86 \mathrm{U} / \mathrm{L})$ after which the activity decreased over time (Fig. 1). An interesting data that can be observed in non-sterile condition is that the phenolic compounds removal remained almost constant although the laccase activity decreased. This suggests the possible existence of other enzymes in T. versicolor for phenol degradation. Du et al. [19], support that different oxidative enzymes are involved in the metabolism of $T$. versicolor. $T$. versicolor F21 shows antagonistic behavior on the cyanobacteria Microcystis spp. by degrading the cyanobacteria with extracellular hydrolases and ligninolytic enzymes. They observed that the enzymes cellulose, $\beta$-glucosidase, protease and laccase are vital to Microcystis spp. degradation in the early stage of incubation $(0 \mathrm{~h}$ to $24 \mathrm{~h})$ but at $24 \mathrm{~h}$ to $60 \mathrm{~h}$ appeared manganese peroxidase $(\mathrm{MnP})$. These authors discussed that microcystin can induce oxidative stress in $T$. versicolor,

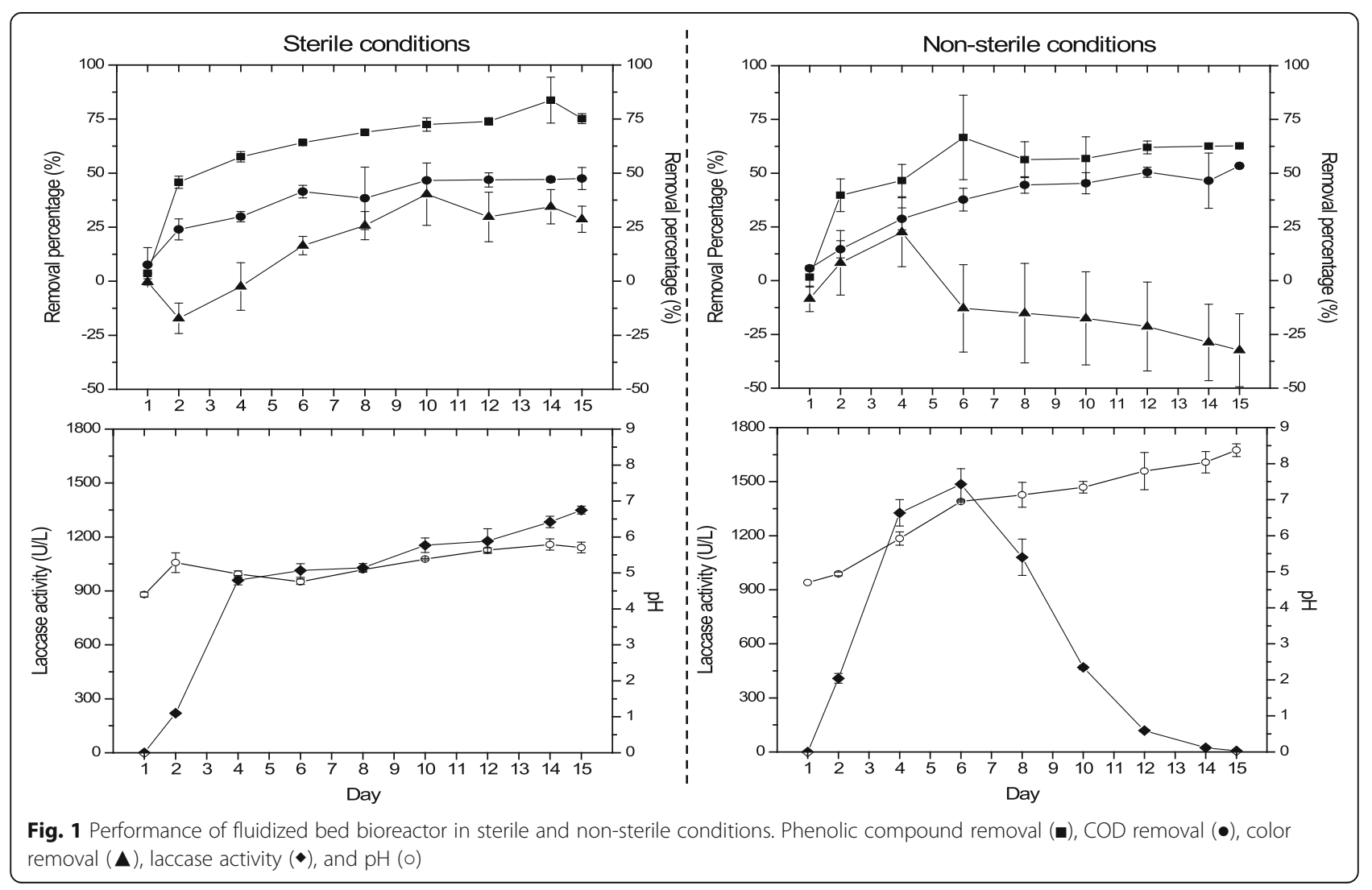


subsequently, the $\mathrm{H}_{2} \mathrm{O}_{2}$-producing enzymes such as glucose oxidase are synthesized in fungal cells to avoid the oxidative damage, and then the degradation reaction of $\mathrm{MnP}$ to microcystin is activated by the intracellular $\mathrm{H}_{2} \mathrm{O}_{2}$. This suggests that in non-sterile condition is probable that some compound induced oxidative stress in T. versicolor and $\mathrm{MnP}$ was produced.

\section{Color removal and $\mathrm{pH}$}

With respect to color variation and $\mathrm{pH}$, the performance is different in both conditions. In sterile, on day 2 and 4 an increase in color was observed and it was not until day 6 that a removal value of $16 \pm 4 \%$ was registered, reaching the maximum on day 10 with a removal of 40 $\pm 14 \%$. On the other hand, in a non-sterile condition, the color variation is large and the average values are in negative values. During sterile condition, the $\mathrm{pH}$ was 4.07 on day zero. But, the $\mathrm{pH}$ reached 5.6 at day 12 and remained constant until day 15 . Likewise, in non-sterile condition the $\mathrm{pH}$ was between 4 and 6 during the first 6 days of operation of the reactor and increased to 8 in the following days (Fig. 1).

Table 2 showed several works on vinasse degradation. It was observed that the values found on the literature with respect to color removal are higher than those found in this study due to highest color removal value $40 \pm 14 \%$ in a sterile condition and color removal in non-sterile condition was not observed. Dahiya et al. [20] said that the better color elimination in sterile condition could have been due to structural changes in compounds when the wastewater was treated at high temperature $\left(121^{\circ} \mathrm{C}\right)$.

As can be seen in the Table 2, a lower $\mathrm{pH}$ value in the vinasse shows a higher decolorization. Benito et al. [21] evaluated the vinasse treatment with two different $\mathrm{pH}$ and reported when the vinasse had a $\mathrm{pH}$ value of $8, T$. versicolor showed almost no growth, COD removal was not produced and only a slight color elimination (10\%) was obtained. Figure 1 shows that higher decolorization was in sterile condition. Our bioreactor operated in sterile condition kept a pH value between 4 and 6 , unlike non-sterile condition where the $\mathrm{pH}$ increased higher to 8. Therefore, it can be suggested that the $\mathrm{pH}$ affected decolorization in the fluidized bed bioreactor with nonsterile condition.

Sun et al. [22], reported that increasing the $\mathrm{pH}$ in vinasse fungi treatment from 5 to 6 seemed to be unfavorable for laccase activation and is responsible for the decrease in its production. This finding might be attributed to the accumulation of fungal metabolic products in the growing culture which inactivates laccase or inhibits its biosynthesis or the action of proteolytic enzymes. On the other hand, Shayegan et al. [23] mentioned that decolorization can reach a maximum value and then decrease slightly, while the $\mathrm{pH}$ increase due to repolymerization of melanoidin. Strong [24] in the treatment of Amarula distillery wastewater $(27 \mathrm{~g} / \mathrm{L}$ of COD and $866 \mathrm{mg} / \mathrm{L}$ of phenolic compounds) with Trametes pubescens reported that the concentration of phenolic compounds would lead to a great increase in color when the $\mathrm{pH}$ increased from 3.8 to neutral. The color change observed may be attributable to the conversion of the phenol to the quinone version in a hydroxyl-rich solution (by abstraction of the hydrogen cation from the $\mathrm{OH}$ group of the phenol). Also, it is known that the first step for degradation by fungi is adsorption [24, 25], and $\mathrm{pH}$ of the solution affects this step because the fungal cell wall is composed of polysaccharides (i.e., chitin and chitosan), proteins, lipids, and melanin with several functional groups (amino, carboxyl, thiol, and phosphate groups) capable of binding various organic molecules. The ionic forms of these

Table 2 Summary of the vinasse treatment under sterile and non-sterile conditions

\begin{tabular}{|c|c|c|c|c|c|c|}
\hline Microorganism & Substrate & $\mathrm{pH}$ & $\begin{array}{l}\text { COD } \\
\text { removal (\%) }\end{array}$ & $\begin{array}{l}\text { Phenolic } \\
\text { removal (\%) }\end{array}$ & $\begin{array}{l}\text { Color } \\
\text { removal (\%) }\end{array}$ & Reference \\
\hline T. versicolor & Cane molasses vinasse $10 \%$ v/v sterile & 5.6 & $41 \pm 3$ & 64 & $16-40$ & This study \\
\hline T. versicolor & Cane molasses vinasse $10 \%$ v/v non-sterile & $6-8$ & $38 \pm 5$ & 67 & 0 & This study \\
\hline T. versicolor & $\begin{array}{l}\text { Beet molasses vinasse }+ \text { sucrose and } \mathrm{KH}_{2} \mathrm{PO}_{4} \text { sterile conditions } \\
\text { not specified }\end{array}$ & 5 & 77 & na & 82 & Benito et al. [21] \\
\hline T. versicolor & $\begin{array}{l}\text { Beet molasses vinasse }+ \text { sucrose and } \mathrm{KH}_{2} \mathrm{PO}_{4} \text { sterile conditions } \\
\text { not specified }\end{array}$ & 8 & $\begin{array}{l}\text { It was not } \\
\text { observed }\end{array}$ & na & 10 & Benito et al. [21] \\
\hline $\begin{array}{l}\text { Corioulus } \\
\text { hirsutus }\end{array}$ & Diluted molasses distillery sterile & 4.5 & 63 & na & 42 & Sun et al. [22] \\
\hline Aspergillus-UB2 & Vinasse non-sterile & 3 & na & na & 84 & Shayegan et al. [23] \\
\hline $\begin{array}{l}\text { Trametes } \\
\text { pubescens }\end{array}$ & Amarulla distillery wastewater sterile & 7 & 73 & 86 & 0 & Strong $[24]$ \\
\hline $\begin{array}{l}\text { Corioulus sp. } \\
\text { No. } 20\end{array}$ & Melanoidins pigments + glucose and sorbose sterile & 4.5 & na & na & 80 & Watanabe et al. [27] \\
\hline Aspergillus niger & Beet molasses vinasse y sucrose sterile & na & na & na & 45 & Miranda et al. [28] \\
\hline
\end{tabular}


organic compounds in solution and the surface electrical charge of the biomass depend on the $\mathrm{pH}$ solution. Therefore, the interaction between a sorbate and sorbent is mainly affected by ionization states of the functional groups on both the molecule and sorbent surface. On the fungi Neurospora intermedia the most suitable $\mathrm{pH}$ for sorption is 3 , and there was a decrease in the extent of bioadsorption potential with increase in the $\mathrm{pH}$ of the solution to values higher than 6 [26].

As can be seen on Table 2, when sugars were added to the vinasse the decolorization was high [21, 27, 28]. Paradoxically, the first studies on the enzymatic system involved in decolorization of vinasse did not focus on ligninolytic enzymes. In fact, intracellular sugar oxidase enzymes were considered as having the most important role in decolorization [29]. The enzyme catalyzing melanoidin decolorization was proved to be L-sorbose oxidase. However, glucose oxidase also decolorized melanoidin pigments. Melanoidin was suggested to be decolorized by the active oxygen $\left(\mathrm{O}_{2}^{-}, \mathrm{H}_{2} \mathrm{O}_{2}\right)$ produced by the reactions with these oxidases because the reaction with the pure enzyme was accompanied by the oxidation of glucose to gluconic acid [27]. In our study, nutrients like sucrose were not added, the sugar oxidase enzymes were not present during the treatment of vinasse in the fluidized bed bioreactor and that is why the decolorization was lower with respect to the other authors. On the other hand, it was observed induction of laccase activity in the fluidized bed reactor in sterile and non-sterile condition, but no clear correlation with effluent decolorization was observed. This is similar to the report by Yang et al. [30] during dye wastewater treatment, they reached over $80 \%$ color removal using white rot fungi but only very low laccase, lignin peroxidase, and manganese dependant peroxidase activities were measured along the whole running process. Thus, no clear correlation about enzymes over decolorization was detected.

\section{Final dry mass}

Final dry mass was measured at the end of both experiments. In sterile condition at day 15 the dry mass was $2.51 \pm 0.6 \mathrm{~g} / \mathrm{L}$ and the morphology of fungal pellets of $T$. versicolor was in the form of compact spherical (Fig. 2a) while at non-sterile condition at day 15 the dry mass was $1.2 \pm 0.22 \mathrm{~g} / \mathrm{L}$, which was less than initial concentration and the pellets were found disrupted (Fig. 2b). Espinosa-Ortiz et al. [31] mentioned that the robust design of bioreactors to maintain similar performance under sterile and non-sterile conditions is often a challenging task that has not been addressed adequately in the literature, however it was reported that the presence of bacteria on some the fungal system may create competition for the substrate, provoke disruption of the fungal growth, damage the fungal mycelium or reduce the expression of the fungal enzymes, ultimately even leading to the deterioration of the fungal activity.

\section{Selection of non-sterile conditions}

The phenolic compounds affect severely the anaerobic process and we obtained similar phenolic compound removal in both sterile and non-sterile conditions in FBR; therefore, it was decided to continue the study in non-sterile conditions since this represents an advantage for future industrial application. Especially, significant energy saving may be possible when the production media large volume are directly used without sterilization [32].

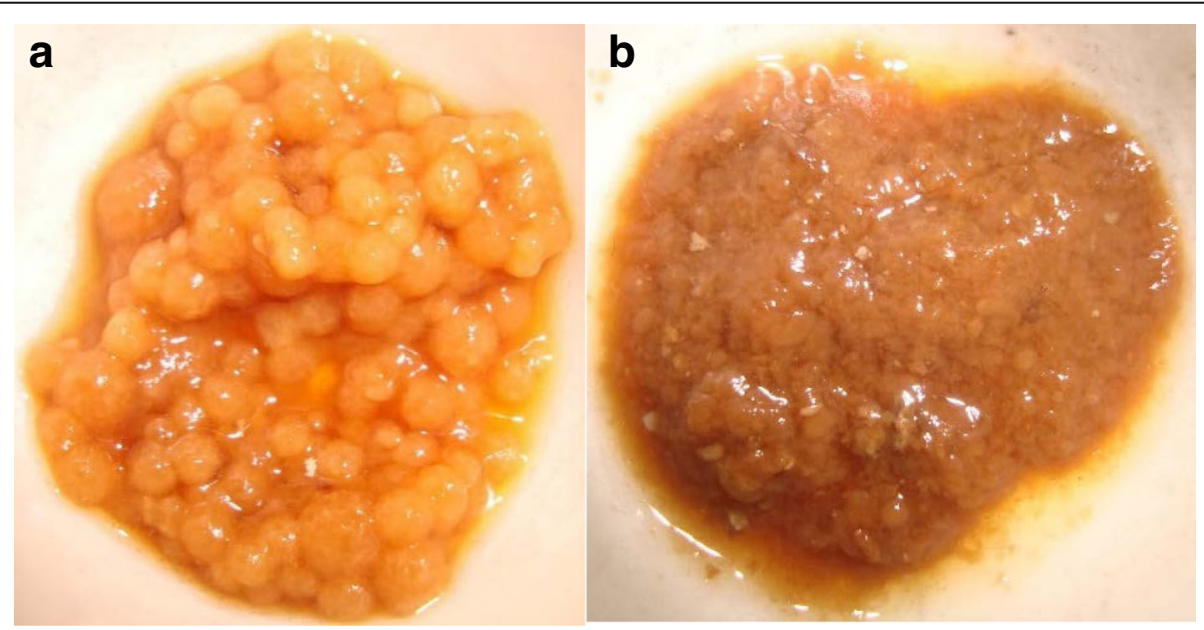

Fig. 2 Morphology of pellets of T. versicolor: a) Sterile condition b) Non-sterile condition 
Non-sterile continuous fluidized bed bioreactor treatment Phenolic compounds and COD

In order to obtain feeding for the UASB, the fluidized bed aerobic bioreactor was operated in continuous. Figure 3 shows the performance of the reactor. The initial phenolic concentration in the fluidized bed bioreactor was $1,247 \pm 31 \mathrm{mg} / \mathrm{L}$ and on day 3 a removal value of $66 \pm 5 \%$ was registered, and this value remained almost constant until the last day of experimentation (day 26). For COD removal, the initial COD concentration was $10,095 \pm 31 \mathrm{mg} / \mathrm{L}$ and on day 3 a value of $37 \% \pm 0.8 \%$ was observed. This value continued increasing slightly until reaching a value higher than 50\%. The COD removal is different as found in batch operation, suggesting that the continuous operation favors the degradation of this parameter.

\section{Laccase activity}

Laccase activity registered a higher value of $550 \pm 53 \mathrm{U} / \mathrm{L}$ on day 6, which decreased in function of the time. This value did not increase although the fungal biomass was renovated which this is probably due to contamination of the medium with bacteria. The results obtained suggest the possible existence of other enzymes in $T$. versicolor for phenol degradation as it was previously mentioned.

\section{Color removal}

With respect to color variation, the performance is similar to batch operation due to not observing a high removal value in all the experiment (Fig. 3).
There is little information about vinasse degradation with fungi in reactors operated in continuous mode and most works are focused on the elimination of color and COD. Shayegan et al. [23], during continuous decolorization of anaerobically digested (UASB) distillery wastewater, Aspergillus-UB2 was cultivated and transferred to an aeration tank and a maximum level of decolorization of $84 \%$ was reached. The efficiency dropped sharply after $96 \mathrm{~h}$. A microscopic examination showed that, due to microbial contamination, the activity of UB2 ceased. It was concluded that it was impossible to work with a reactor for more than a few days and keep the system uncontaminated. In another study, wastewater from a baker's yeast factory, previously treated by methane fermentation and with activated sludge, was treated in a bubbling column reactor operated in continuous. They reached a decolorization yield of $75 \%$, but maintenance of this condition for a long time could not be stably performed and the decolorization yield decreased gradually after $25 \mathrm{~h}$ reaction. Each mycelium becomes small and short because of the bubbling shock and is either washed out from the reactor or undergoes autolysis [33].

Miranda et al. [28] investigated the degradation of vinasse in a jacked tubular reactor. The operation started working as a batch culture and when the color removal was around 40\% (3 days), the reactor was continuously fed with wastewater and nutrients determined at a flow rate of $1 \mathrm{~L} /$ day (HRT of 5 days). The maximum color removal during the continuous process was $37 \%$ and it kept constant for 3-4 days; after this time, the absorbance of

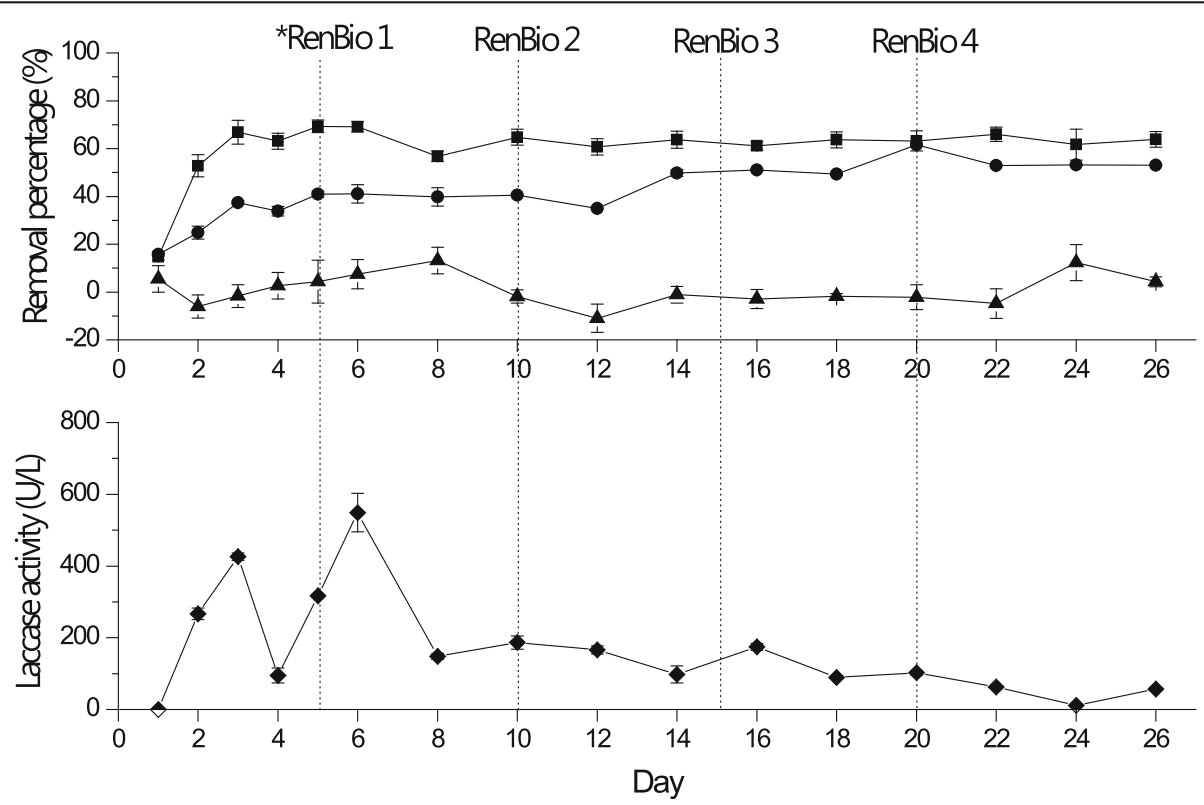

Fig. 3 Performance of fluidized bed bioreactor in non-sterile condition operated in continuous. Phenolic compound removal ( $\mathbf{a})$, COD removal $(\bullet)$, color removal $(\mathbf{\Delta})$ and laccase activity $(\bullet){ }^{*}$ Ren Bio refers to renovation of $\mathrm{T}$. versicolor biomass inside the bioreactor 
the effluent increased, the COD removal was around 69\% and the results obtained in the continuous culture indicate a low color removal for a short period of time.

\section{FBR coupled to the UASB reactor}

With the aim of better understanding the discussion of this section, we defined System 1 as the vinasse Untreatment (diluted) affluent to the UASB reactor and System 2 as the fluidized bed bioreactor coupled with UASB reactor. Both systems had a COD of around $7 \mathrm{~g} / \mathrm{L}$ in affluent to the UASB, because in Mexico, the application of crude vinasse in the crops had been diluted between $7 \%$ and $10 \% \mathrm{v} / \mathrm{v}$ with water in order to use it in fertigation. Table 3 shows the characterization of affluent and effluents obtained in systems 1 and 2. According to statistical analysis, the effluent generated in the UASB reactor in each system presented significant differences in all parameters with exception of COD and $\mathrm{PO}_{4}^{3-}$, suggesting that the UASB effluent of System 2 has better quality for environmental reuse due to lower values of the parameters measured than System 1. Although, there is no significant difference in COD removal of effluent, in Table 3 it can be observed that System 1 had a COD removal of $48 \pm 2 \%$ while System 2 had a higher total COD removal of $64 \pm 3 \%$. This is in accordance to what is reported by Apollo et al. [34] where coupling an ultraviolet photodegradation with an anaerobic digestion process improved the efficiency in COD removal in a real distillery effluent and raw molasses wastewater.

Strong [35], in the treatment of wine distillery wastewater, reported that the fungally-treated samples all had much lower initial color absorbance values and the color increased in a number of the samples after anaerobic treatment of the fungally-pretreated. It is possible that some of the compounds that were depolymerized by the fungal treatment were repolymerized during the anaerobic treatment or possibly due to the increase in $\mathrm{pH}$. In this study, the color in both systems remained constant between affluent and effluent (Table 3).

With respect to phenolic compounds, System 1 did not show a removal value, suggesting that anaerobic digestion in the UASB operated under our conditions is not able to degrade these compounds. Strong [35] detected that the final removal efficiencies of phenol were generally better for anaerobic digestion than for the fungal treatment; however, these removal values were obtained within 2 weeks. In another study, the authors indicated that conversion of phenol and p-cresol is favorable under methanogenic conditions, but a lag phase of 30 days was observed [36]. In our study the UASB was operated with a HRT of 6 days, which is lower than the values reported by other authors for degradation of phenolic compounds. On the other hand, system 2 reached a phenolic compound removal of $52 \pm$ $5 \%$, but it can be detected that the effluent of UASB showed a higher value of phenolic compounds compared with the effluent of fluidized bed bioreactor. This is probably due to cell lysis of pellets of $T$. versicolor that could be mixed in the affluent of the UASB reactor. As it was mentioned previously, the biodegradation for fungi is by adsorption and it is probable that the compounds adsorbed or absorbed by $T$. versicolor were released in the UASB. Figure 4 presents the biogas production and methane content in the biogas for both systems. System 1 registered a higher biogas production $(2,370 \pm 149 \mathrm{~mL})$ compared with System $2(1,102 \pm 83$ $\mathrm{mL})$; however, System 2 reached a higher methane content in biogas $(74 \pm 6 \%)$ than System $1(65 \pm 5 \%)$. The statistical analysis showed that these values have significant difference. With these results we found that the methane yield was 0.28 and $0.18 \mathrm{~m}^{3} \mathrm{CH}_{4} / \mathrm{kg} \mathrm{COD}$ removal for System 1 and System 2, respectively.

Jiménez et al. [4] reported that the pretreatment of distillery wastewater with Penicillium decumbens reduced

Table 3 Characterization of influent and effluent in systems 1 and 2

\begin{tabular}{|c|c|c|c|c|c|}
\hline & System 1 & & System 2 & & \\
\hline Parameter & Vinasse (diluted 7\% v/v) & UASB effluent & Vinasse (diluted 10\% v/v) & Fluidized bed bioreactor effluent & UASB effluent \\
\hline COD & $7,704 \pm 800$ & $4,000 \pm 570^{a}$ & $11,000 \pm 1,000$ & $7,000 \pm 93$ & $3,940 \pm 42^{a}$ \\
\hline Phenolic compounds & $758 \pm 100$ & $840 \pm 42^{a}$ & $1,083 \pm 150$ & $460 \pm 40$ & $519 \pm 10^{\mathrm{b}}$ \\
\hline Color* & $0.10 \pm .001$ & $0.11 \pm 0.003^{a}$ & $0.13 \pm 0.012$ & $0.13 \pm 0.003$ & $0.14 \pm 0.005^{b}$ \\
\hline $\mathrm{SO}_{4}^{2-}$ & $371 \pm 90$ & $200 \pm 56^{a}$ & $530 \pm 141$ & $540 \pm 50$ & $70 \pm 40^{b}$ \\
\hline TN & $120 \pm 15$ & $723 \pm 52^{a}$ & $172 \pm 21$ & $688 \pm 79$ & $408 \pm 91^{b}$ \\
\hline $\mathrm{N}-\mathrm{NH}_{3}$ & $5 \pm 0.6$ & $57 \pm 1^{a}$ & $7 \pm 1$ & $5 \pm 0.7$ & $31 \pm 4^{b}$ \\
\hline $\mathrm{PO}_{4}^{3-}$ & $29 \pm 5$ & $49 \pm 6^{a}$ & $41 \pm 7$ & $22 \pm 2$ & $46 \pm 7^{a}$ \\
\hline Biogas production** & - & $2,370 \pm 149^{a}$ & - & - & $1,102 \pm 83^{b}$ \\
\hline Methane content ${ }^{* * *}$ & - & $65 \pm 5^{\mathrm{a}}$ & - & - & $74 \pm 6^{b}$ \\
\hline
\end{tabular}

All values are expressed in $\mathrm{mg} / \mathrm{L},{ }^{*}$ Color is the absorbance at $475 \mathrm{~nm},{ }^{*}$ Biogas production at $\mathrm{mL},{ }^{* * *}$ Methane content at percentage. Each value is a mean \pm SD. Different case letters indicate significant difference between means of UASB effluent in System 1 and System 2 for each parameter (One-way ANOVA, multiple range test, $P<0.05)$ 

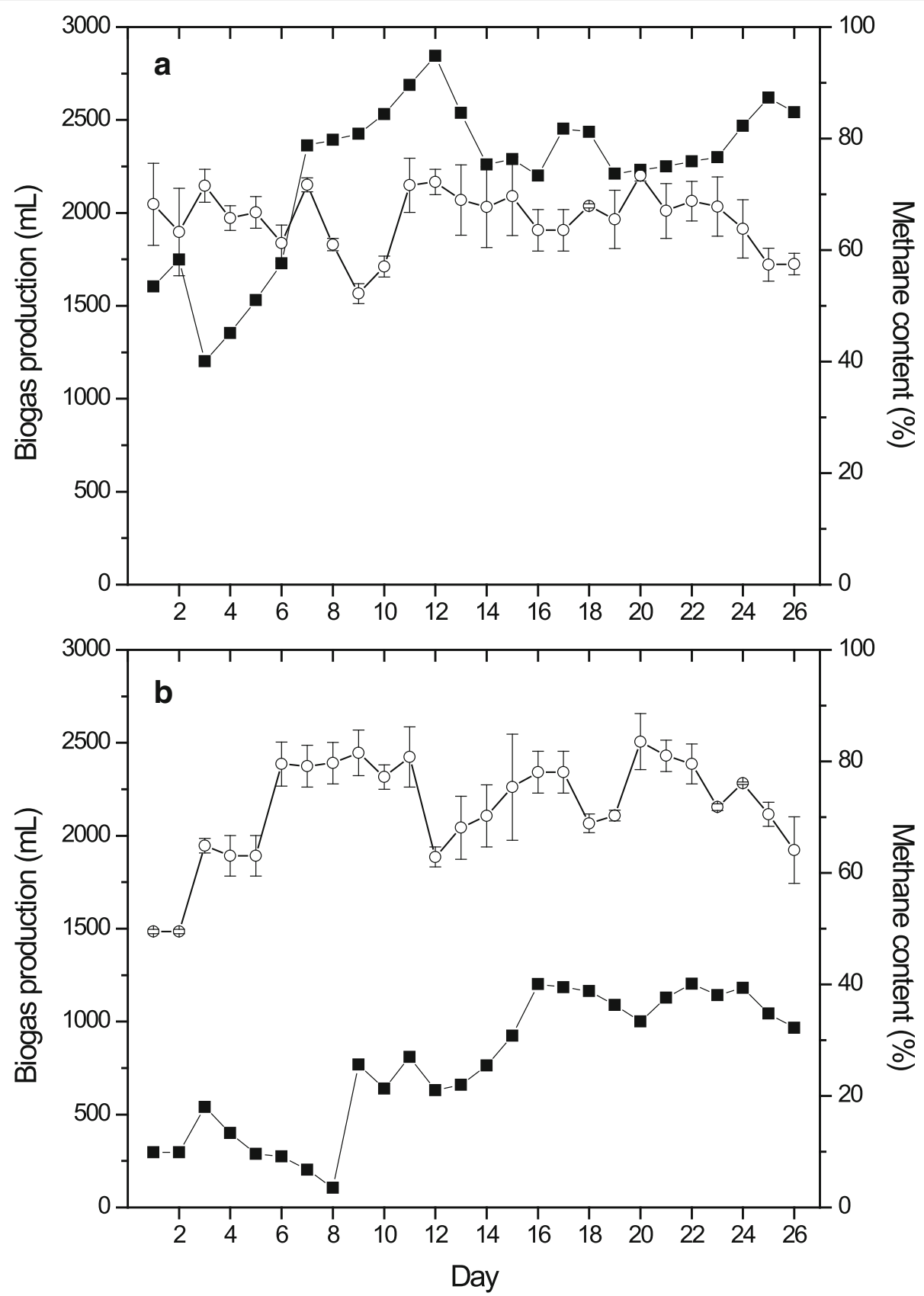

Fig. 4 Performance of biogas production and methane content in biogas in: a) System 1 and b) System 2. Biogas production ( $\mathbf{})$ and methane content $(O)$

67.7\% initial concentration of phenolic compounds. Later, they realized anaerobic digestion in a continuous stirred reactor of vinasses with and without treatment with $P$. decumbens. Those authors obtained a methane yield of 0.2 $\mathrm{m}^{3} \mathrm{CH}_{4} / \mathrm{kg} \mathrm{COD}_{\text {added }}$ with a HRT of 53 days and an OLR of $1.5 \mathrm{~kg} \mathrm{COD} / \mathrm{m}^{3}$ day with non-treated vinasse; likewise, with the same OLR of treated vinasse, was registered a methane yield of $0.225 \mathrm{~m}^{3} \mathrm{CH}_{4} / \mathrm{kg} \mathrm{COD}$ added with a HRT of 15 days. Reaching an increase of $12 \%$ in the methane yield. In our study, using a ORL similar to Jiménez et al. [4] $\left(1.2 \mathrm{~kg} \mathrm{COD} / \mathrm{m}^{3}\right.$ day) were obtained good yields for both systems $\left(0.28\right.$ and $0.18 \mathrm{~m}^{3} \mathrm{CH}_{4} / \mathrm{kg} \mathrm{COD}_{\text {removed }}$ for system 1 and 2 respectively) with a HRT of 6 days. However, the methane yield did not increase in system 2 due that a decrease in the biogas production was observed. Because, in system 2 the $\mathrm{BOD}_{5}$ in the effluent of FBR inoculated with $T$. versicolor (affluent UASB) was $609 \mathrm{mg} / \mathrm{L}$, suggesting that $T$. versicolor consumed large quantities of 
the biodegradable organic matter $\left(85 \% \mathrm{BOD}_{5}\right.$ removal). Similar results were presented by Ferreira et al. [37], who removed $75 \%$ of $\mathrm{BOD}_{5}$ in sugar cane vinasse when it was treated with Pleurotus sajor-caju. Also Kida et al. [38], reported the treatment of Schochu distillery wastewater with Aspergillus awamori var. kawachi, they found that the $\mathrm{BOD}_{5}$ removal was $56 \%$; therefore, these works showed that a fungus is able to degrade more than $50 \%$ of biodegradable organic matter on vinasse.

On the other hand, in the System 1 the $\mathrm{BOD}_{5}$ (affluent UASB) was $3,500 \mathrm{mg} / \mathrm{L}$ according to a vinasse untreated (approximately $40 \%$ of COD) and its value is agree to prior review of the literature $[1,39]$. This result suggests that the organic matter available in the UASB reactor was more easily biodegradable and this is reflected in the high biogas flow. However, although the COD was the same in both systems, COD in system 2 could be masked by a greater amount of oxidizable inorganic compounds as nitrites, sulfides, and chlorides found in higher concentration, as shown in Table 3 [40]. Furthermore, the methane content in system 2 was higher, because Trametes versicolor was able to remove more than $50 \%$ of the phenols present in the vinasse and it has been mentioned previously that these phenolic compounds inhibit to methanogenic microorganisms [4].

Although a lower amount of biogas was obtained in system 2 , this presented the best quality to be used in the production of electricity since the common methane content in the crude gas must be at least $65 \%[41]$.

\section{Experimental procedures Fluidized bed bioreactor Batch treatment}

A glass fluidized bed bioreactor with a useful volume of 2 L, described by Blánquez et al. [42], was used to carry out both sterile and non-sterile vinasse treatment. The vinasse was diluted at $10 \% \mathrm{v} / \mathrm{v}$ with distilled water, given that crops in Mexico are currently irrigated at this concentration. Approximately, $2.4 \mathrm{~g}$ dry weight pellets/L were inoculated in sterile and non-sterile treatments. Fungal biomass was maintained with an air flow of $10 \mathrm{~L} / \mathrm{h}$ generated by an air pump. The $\mathrm{pH}$ was not controlled and the temperature was maintained at $25{ }^{\circ} \mathrm{C}$. For sterile conditions the bioreactor and the diluted vinasse were autoclaved at $121{ }^{\circ} \mathrm{C}$ for 20 min. Samples of $20 \mathrm{~mL}$ were taken daily during the first two days and subsequently each second day during the 15 days of experimentation. The samples were used to measure COD, phenolic compounds, color and laccase activity. The dry weight of mycelium mass was measured $\left(105{ }^{\circ} \mathrm{C}\right.$ for $24 \mathrm{~h}$ ) at the end both experimental conditions.

\section{Continuous treatment}

The bioreactor was operated in continuous in non-sterile conditions for 26 days. The $\mathrm{pH}$ was maintained at 4.5 with a pH controller (ALPHA PH 560, Thermo Scientific). Hydraulic retention time (HRT) was 6 days, which was established based on the result obtained in the batch treatment. The biomass renovation methodology reported by Blánquez et al. [43] was used to extend the operational time. This strategy must allow continuous long-term operation to maintain satisfactory degradation percentages and extracellular enzymatic production. The inoculum, air flow and temperature were the same as in the batch experiment. Samples of $20 \mathrm{~mL}$ were taken daily during the first six days and subsequently each second day. The samples were used to measure COD, phenolic compounds, color and laccase activity.

\section{Upflow anaerobic sludge blanket System 1}

A UASB reactor with an operational volume of $4.2 \mathrm{~L}$ was operated under mesophilic conditions $\left(30 \pm 5{ }^{\circ} \mathrm{C}\right)$ using a water bath WiseCircu ${ }^{\oplus}$. HRT was 6 days. The reactor was fed daily with $700 \mathrm{~mL}$ of ethanol hydrous vinasse diluted at $7 \% \mathrm{v} / \mathrm{v}$ which is equivalent to an organic loading rate (OLR) of $1.2 \mathrm{~kg} \mathrm{COD} / \mathrm{m}^{3}$ day. A $\mathrm{pH}$ of 7.0 was maintained using sodium bicarbonate $\left(\mathrm{NaHCO}_{3}\right)$ as a buffer. The bioreactor was kept at a minimum operation time of 4 times the HRT (26 days). During the reactor operation, COD, phenolic compounds, color, total nitrogen (TN), ammonia nitrogen $\left(\mathrm{N}-\mathrm{NH}_{3}\right)$, phosphate $\left(\mathrm{PO}_{4}^{3-}\right)$, and sulfate $\left(\mathrm{SO}_{4}^{2-}\right)$ were measured each second day. Gas production and methane content in biogas were measured daily.

\section{System 2}

The same UASB reactor was operated under identical operational conditions with system 1 . The only difference was that it was fed daily with $700 \mathrm{~mL}$ vinasse previously treated in a fluidized bed bioreactor with $T$. versicolor equivalent to an OLR of $1.2 \mathrm{~kg} C O D / \mathrm{m}^{3}$-day. This was done in order to find if a fungal pretreatment step was beneficial for the anaerobic digestion. The monitoring of the system was performed identically to system 1 .

\section{Analytical procedures}

$\mathrm{COD}, \mathrm{TN}, \mathrm{N}-\mathrm{NH}_{3}, \mathrm{PO}_{4}^{3-}$ and $\mathrm{SO}_{4}^{2-}$ contents were determined via colorimetric methods (Hach Company DR890), whilst the $\mathrm{pH}$ was determined in accordance with American Public Health Association [44].

Phenolic compounds were estimated with FolinCiocalteu reagent where $20 \mu \mathrm{L}$ of sample and 1.58 $\mathrm{mL}$ distilled water were placed in an amber-colored flask. $300 \mu \mathrm{L}$ sodium carbonate solution (20\% weight/ volume) and $100 \mu \mathrm{L}$ of, Folin-Ciocalteu reagent were then added in rapid succession, mixed and left to 
react for $60 \mathrm{~min}$ in darkness at room temperature. After the reaction time, absorbance at a wavelength of $765 \mathrm{~nm}$ was measured with a spectrophotometer Cole Parmer S2100-UV+ (Cole Parmer, USA). Gallic acid was used as the standard for plotting the calibration curve.

For color determination, the samples were centrifuged at $1,037 \mathrm{~g}$ for $10 \mathrm{~min}$. They were then diluted to $10 \%$ and measured with a spectrophotometer Cole Parmer S2100UV+ (Cole Parmer, USA) at wavelength of $475 \mathrm{~nm}$ [45].

Laccase activity was determined according to $\mathrm{Li}$ et al. [46], following the rate of oxidation of $5 \mathrm{mM}$ ABTS (2,2'-azinobis(3-ethylbenzothiazoline-6-sulfonic acid) as a substrate. The measurements were made in $100 \mathrm{mM}$ sodium acetate buffer $(\mathrm{pH} 5)$ at $30{ }^{\circ} \mathrm{C}$. Oxidation was measured at $420 \mathrm{~nm}\left(\varepsilon_{420}=36,000 \mathrm{M}^{-1} \mathrm{~cm}^{-1}\right)$. One activity unit $(\mathrm{U})$ was defined as the number of micromoles of ABTS oxidized per minute.

The volume of biogas produced was measured every $24 \mathrm{~h}$ with a gasometer (Milligascounter) and biogas methane concentration was determined with a GC Clarus 500-Perkin Elmer equipped with a thermal conductivity detector (TCD) and a Molesieve column, according to España-Gamboa et al. [47].

\section{Statistical analysis}

The optimization experiments were conducted in duplicate. Sampling was done in triplicates and the statistical differences were determined using a one way analysis of variance (ANOVA) with multiple range test using Statgraphics Centurion XVI.

\section{Conclusions}

This study demonstrated the possibility of using a FBR for the elimination of recalcitrant compounds and COD at non-sterile conditions by $T$. versicolor. This shows that significant energy saving may be possible when the production media large volume (industrial application) are directly used without sterilization. Continuous operation of the fluidized bed bioreactor was carried out successfully for 26 days, which is the highest value found in the literature. Two systems were evaluated for the vinasse treatment in which System 2 coupled the FBR to the UASB reactor and registered the best quality of effluent and higher methane content in the biogas.

Conclusively, the coupling of FBR to UASB reactor is a promising environmental technology for the treatment of vinasse; nevertheless, an economic study and feasibility of application of the process to full scale is necessary.

\section{Abbreviations}

ABTS: 2,2'-azino-bis(3-ethylbenzothiazoline-6-sulphonic acid); ANOVA: Analysis of variance; BOD: Biochemical oxygen demand; COD: Chemical oxygen demand; FBR: Fluidized bed reactor; HRT: Hydraulic retention time; MnP: Manganese

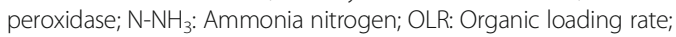

PAHs: Polycyclic aromatic hydrocarbons; PCBs: Polychlorobiphenyls; $\mathrm{PO}_{4}^{3-}$ : Phosphate; $\mathrm{SO}_{4}^{2-}$ : Sulfate; TCD: Thermal conductivity detector; TN: Total nitrogen; UASB: Upflow anaerobic sludge blanket

\section{Acknowledgements}

Vinasse was obtained courtesy of sugar factory "La Gloria." Furthermore, we thank Gloria Caminal, Paqui Blánquez, Xavier Font and Silvia Contreras for their comments and assistance in specific techniques. The authors wish to express their thanks to Gerardo Cámara, Francisco del Río and Miguel Tzec for their technical support.

\section{Funding}

National Council of Science and Technology Mexico (CONACYT) for the financial support granted to carry out this study through grant 234317 awarded for PhD studies.

\section{Availability of data and materials}

The dataset supporting the conclusions of this article is included within the article.

\section{Authors' contributions}

EEG performed the experiments presented herein and helped draft the manuscript and assisted in experimental design of the FBR and UASB. TV, XF and BCC developed a methodology to obtain growth of fungi in the form of pellets, identification analysis of strain, and assisted in drafting the manuscript. JDM developed the carboxylic acids analysis. LMAG, she conceived of the study and financed, supervised the work, designed the coupled system and drafted the manuscript. All authors participated in the experimental design, evaluation of the data, reading and approval final manuscript.

\section{Competing interests}

The authors declare that they have no competing interests.

\section{Consent for publication}

The authors declare that: Our manuscript does not contain any individual person's data, therefore, "Not applicable".

\section{Ethics approval and consent to participate}

The authors declare that: They have answered "NO" to the question "Does your manuscript report data collected from humans or animals?"

\section{Author details}

${ }^{1}$ Yucatan center for scientific research (CICY), Renewable Energy Unit and Biotechnology Unit. Street 43 N.130 Col. Chuburná de Hidalgo 97200, Merida, Yucatan, Mexico. ${ }^{2}$ Departament d'Enginyeria Química, Escola Técnica Superior d'Enginyeria, Universitat Autònoma de Barcelona, Bellaterra, 08193 Barcelona, Spain.

Received: 20 April 2016 Accepted: 8 December 2016

Published online: 23 January 2017

\section{References}

1. España-Gamboa E, Mijangos-Cortés J, Barahona-Pérez L, Dominguez-Maldonado J, Hernandez-Zárate G, Alzate-Gaviria L. Vinasse: characterization and treatments. Waste Manage Res. 2011:29:1235-50.

2. Reis CMd, Carosia MF, Sakamoto IK, Varesche MBA, Silva EL. Evaluation of hydrogen and methane production from sugarcane vinasse in an anerobic fluidized bed reactor. Int J Hydrogen Energ. 2015;40:8498-509.

3. González L, Mejía M. Impact of ferti-irrigation with vinasse on ground water quality. Irrig Drain. 2015;64:400-7.

4. Jiménez A, Borja R, Martín A, Raposob F. Kinetic analysis of the anaerobic digestion of untreated vinasses and vinasses previously treated with Penicillium decumbens. J Environ Manage. 2006;80:303-10.

5. Vlyssides A, Barampouti EM, Mai S, Stamatoglou A, Tsimas E. Alternative biological systems for the treatment of vinasse from wine. Water Sci Technol. 2010;62:2899-904.

6. Moraes BS, Zaiat M, Bonomi A. Anaerobic digestion of vinasse from sugarcane ethanol production in Brazil: Challenges and perspectives. Renew Sust Energ Rev. 2015:44:888-903. 
7. Poirier S, Bize A, Bureau C, Bouchez T, Chapleur O. Community shifts within anaerobic digestion microbiota facing phenol inhibition: Towards early warning microbial indicators? Water Res. 2016; 10.1016/j.watres.2016.05.041

8. Pazarlioglu NK, Sariisik M, Telefoncu A. Laccase: production by Trametes versicolor and application to denim washing. Process Biochem. 2005;40:1673-8.

9. Giardina P, Faraco V, Pezzella C, Piscitelli A, Vanhulle S, Sannia G. Lacasses: a never-ending story. Cell Mol Life Sci. 2010;67:369-85.

10. Catherine $H$, Frédéric $D$, Penninck $M$. Product formation from phenolic compounds removal by laccases: A review. Environmental Technology \& Innovation. 2016; http://dx.doi.org/10.1016/j.eti.2016.04.001.

11. Baldrian P. Fungal laccases - ocurrence and properties. FEMS Microbiol Rev. 2006;30:215-42.

12. Strong PJ, Claus H. Laccase: A review of its past and its future in bioremediation. Crit Rev Env Sci Tec. 2011;41:373-434.

13. Cruz-Morató C, Ferrando-Climent L, Rodriguez-Mozaz S, Barceló D, Marco-Urrea E, Vicent T, Sarra M. Degradation of pharmaceuticals in non-sterile urban wastewater by Trametes versicolor in a fluidized bed bioreactor. Water Res. 2013;47:5200-10.

14. Placková M, Svobodová K, Cajthaml T. Laccase activity profiling and gene expression in PCB-degrading cultures of Trametes versicolor. Int Biodeter Biodegr. 2012;71:22-8.

15. Borras E, Blánquez P, Sarra M, Caminal G, Vicent T. Trametes versicolor pellets production: Low-cost medium and scale-up. Biochem Eng J. 2008;42:61-6.

16. Gros M, Cruz-Morato C, Marco-Urrea E, Longrée P, Singer H, Sarra M, Hollender J, Vicent T, Rodriguez-Mozaz S, Barceló D. Biodegradation of the $X$-ray contrast agent iopromide and the fluoroquinolone antibiotic ofloxacin by the white rot fungus Trametes versicolor in hospital wastewaters and identification of degradation products. Water Resour. 2014;60:228-41.

17. Font X, Caminal G, Gabarrell X, Romero S, Vicent T. Black liquor detoxification by laccase of Trametes versicolor pellets. J Chem Technol Biot. 2003;78:548-54

18. García-García I, Bonilla-Venceslada JL, Jiménez-Peña PR, Ramos-Gómez E. Biodegradation of phenol compounds in vinasse using Aspergillus terreus and Geotrichum candidum. Water Res. 1997;31:2005-11.

19. Du J, Pu G, Shao C, Cheng S, Cai J, Zhou L, Jia Y, Tian X. Potential of extracellular enzymes from Trametes versicolor F21 a in Microcystis spp. degradation. Mater Sci Eng C. 2015:48:138-44.

20. Dahiya J, Singh D, Nigam P. Decolourisation of molasses wastewater by cells of Pseudomonas fluorescens immobilised on porous cellulose carrier. Bioresource Technol. 2001;78:111-4.

21. Benito GG, Miranda MP, Rodriguez De Los Santos D. Decolorization of wastewater from an alcoholic fermentation process with Trametes versicolor. Bioresource Technol. 1997:61:33-7.

22. Sun W, Xu M, Xia C, Li A, Sun G. Enhanced production of laccase by Coriolus hirsutus using molasses distillery wastewater. Front Environ Sci Eng. 2013;7: 200-10.

23. Shayegan J, Pazouki M, Afshari A. Continuos decolorization of anaerobically digested distillery wastewater. Process Biochem. 2005;40:1323-9.

24. Strong PJ. Fungal remediation of Amarula distillery wastewater. World J Microb Biot. 2010;26:133-44.

25. Blánquez $\mathrm{P}$, Casas N, Font X, Gabarrell X, Sarrà M, Caminal G, Vicent T. Mechanism of textile metal dye biotransformation by Trametes versicolor. Water Res. 2004;38:2166-72.

26. Kaushik G, Thakur IS. Adsorption of colored pollutants from distillery spent wash by native and treated fungus: Neurospora intermedia. Environ Sci Pollut Res. 2013:20:1070-8.

27. Watanabe $Y$, Sugi $R$, Tanaka $Y$, Hayashida S. Enzymatic decolorization of melanoidin by Coriolus sp. No. 20. Agric Biol Chem. 1983:46:1623-30.

28. Miranda MP, Benito GG, Cristobal NS, Nieto CH. Color elimination from molasses wastewater by Aspergillus niger. Bioresource Technol. 1996;57:229-35.

29. González T, Terrón MC, Yagüe S, Junca H, Carbajo JM, Zapico EJ, Silva R, Arana-Cuenca A, Téllez A, González AE. Melanoidin-containing wastewaters induce selective laccase gene expression in the white-rot fungus Trametes sp. I-62. Res Microbiol. 2008;159:103-9.

30. Yang $Q, L i C L H, L i$ Y, Yu N. Degradation of synthetic reactive azo dyes and treatment of textile wastewater by a fungi consortium reactor. Biochem Eng J. 2009:43:225-30.

31. Espinosa-Ortiz E, Rene ER, Pakshirajan K, Hullebusch EDV, Lens PNL. Fungal pelleted reactors in wastewater treatment: Applications and perspectives. Chem Eng J. 2016;283:553-71.
32. Arslan NP, Aydogan MN, Taskin M. Citric acid production from partly deproteinized whey under non-sterile culture conditions using immobilized cells of lactose -positive and cold-adapted Yarrowia lipolytica B9. J Biotechnol. 2016; http://dx.doi.org/doi:10.1016/j.jbiotec.2016.05.033.

33. Ohmomo S, Itoh N, Watanabe Y, Kaneko Y, Tozawa Y, Ueda K. Continuos decolorization of molasses waste water with mycelia of Coriolus versicolor Ps4a. Agric Biol Chem. 1985;49:2551-5.

34. Apollo S, Onyango M, Ochieng A. An integrated anaerobic digestion and UV photocatalytic treatment of distillery wastewater. J Hazard Mater. 2013;261:435-42.

35. Strong PJ. Fungal remediation and subsequent methanogenic digestion of sixteen winery wastewaters. S Afr J Enol Vitic. 2008;29:85-93.

36. Cervantes FJ, Svd V, Lettinga G, Field JA. Quinones as terminal electron acceptors for anaerobic microbial oxidation of phenolic compounds. Biodegradation. 2000;11:313-21.

37. Ferreira LF, Aguiar MM, Messias TG, Pompeu GB, Queijeiro AM, Silva DP, Monteiro RT. Evaluation of sugar-cane vinasse treated with Pleurotus sajor-caju utilizing aquatic organisms as toxicological indicators. Ecotoxicol Environ Saf. 2011;74:132-7.

38. Kida K, Morimura S, Abe N, Sonada Y. Biological treatment of Shochu distillery wastewater. Process Biochem. 1995;30:125-32.

39. Christofoletti CA, Escher JP, Correía JE, Urbano JF, Fontanetti CS. Sugarcane vinasse: Environmental implications of its use. Waste Manage. 2013;33:2752-61.

40. Lee E, Lee H, Kim YK, Sohn K, Lee K. Hydrogen peroxide interference in chemical oxygen demand during ozone based advanced oxidation of anaerobically digested livestock wastewater. Int J Environ Sci Tech. 2011;8:381-8.

41. Mohseni F, Magnusson M, Görling M, Alvfors P. Biogas from renewable electricity-Increasing a climate neutral fuel supply. Appl Energ. 2012;90:11-6.

42. Blánquez P, Sarra M, Vicent T. Development of a continuous process to adapt the textile wastewater treatment by fungi to industrial conditions. Process Biochem. 2008:43:1-7.

43. Blánquez P, Sarra M, Vicent T. Study of the cellular retention time and the partial biomass renovation in a fungal decolourisation continuous process. Water Res. 2006;40:1650-6.

44. Federation: APHAAWWAWE. Standard Methods for the Examination of Water and Wastewater. 21st edition. 2005

45. Ferreira LF, Aguiar M. Selection of vinasse degrading microorganisms. World J Microb Biot. 2010;26:1613-21.

46. Li K, Xu F, Eriksson K-El. Comparison of fungal laccases and redox mediators in oxidation of a nonphenolic lignin model compound. Appl Environ Microb. 1999;65:2654-60.

47. España-Gamboa E, Mijangos-Cortés J, Hernández-Zárate G, DominguezMaldonado J, Alzate-Gaviria L. Methane production by treating vinasses from hydrous ethanol using a modified UASB reactor. Biotechnol Biofuels. 2012;5:1-9.

\section{Submit your next manuscript to BioMed Central and we will help you at every step:}

- We accept pre-submission inquiries

- Our selector tool helps you to find the most relevant journal

- We provide round the clock customer support

- Convenient online submission

- Thorough peer review

- Inclusion in PubMed and all major indexing services

- Maximum visibility for your research

Submit your manuscript at www.biomedcentral.com/submit 